\title{
O texto entre a história e a fé
}

Antonio Manzatto

\section{Resumo}

O artigo pergunta pela importância da aproximação entre teologia e literatura, e a percebe positivamente na afirmação das conquistas da exegese literária, e como que necessária no estabelecimento mesmo da reflexão teológica que busca compreender a fé em Deus cuja compreensão passa, necessariamente, pela narratividade. Assim a própria epistemologia teológica é marcada por procedimentos literários.

Palavras-chave: Teologia e Literatura, Epistemologia Teológica, Exegese Literária, Narratividade.

\begin{abstract}
The article asks about the importance of rapprochement between theology and literature, and realize it positively in the affirmation of the achievements of literary exegesis, and as really necessary to establish the theological reflection that seeks to understand the faith in God whose understanding, necessarily, goes by the narrativity. So, the theological epistemology is marked by literary procedures.
\end{abstract}


Keywords: Theology and Literature, Theological Epistemology, Literary Exegesis, Narrativity.

\section{Introdução}

Já há tempos se trabalha, em diversos setores acadêmicos e em muitos lugares, a relação entre teologia e literatura. Pesquisadores de diferentes campos de conhecimento se debruçam sobre uma e outra, descobrindo e/ou criando relações que permitem e ajudam, no final das contas, a melhor entender e compreender o ser humano e sua existência. Tal relação recebe diferentes categorizações e é afirmada ora como diálogo, ora como aproximação, ora como interação. Debate-se, também, quais os métodos de estudo que são possíveis para favorecer tal relação, e se conclui que eles são múltiplos e diversos, permitindo diversas formas de abordagem da relação estabelecida entre elas. Há, inclusive, um consenso em dizer que tal relação não deve se estabelecer com o domínio de uma sobre a outra nem com a descaracterização de alguma delas. Na relação entre teologia e literatura, a teologia deve continuar sendo teologia e a literatura, literatura, e uma não deve reduzir a outra à condição de serva de si mesma. Guardando, pois, a diferença entre si, elas podem relacionar-se, fecundar-se e alimentar as reflexões que são realizadas a partir da contemplação de uma e outra e de sua relação.

O lugar onde se situa aquele que estabelece a relação entre teologia e literatura também pode variar segundo seus interesses específicos. E temos então o fato de se organizarem em diferentes setores diversos grupos de estudo e de pesquisa que trabalham a relação entre teologia e literatura. Temos pesquisadores das áreas de literatura, de linguística, de ciências da religião, de filosofia ou de teologia que trabalham a questão. Seguem métodos e objetivos diferentes, de acordo com o interesse de suas pesquisas e campos de conhecimento. Mas todos, de uma maneira ou de outra, vêem como benéfico o trabalho que relaciona, de maneira mais ampla, arte e religião, e de maneira mais específica, teologia e literatura.

\section{Relação entre teologia e literatura}

Já disse em muitas e diferentes ocasiões que o lugar onde me situo é a teologia, e a partir dela me proponho a estudar a relação que entre si podem 
estabelecer teologia e literatura. Situar-se em teologia tem seus condicionantes próprios, como a confessionalidade da teologia, que garante o primado da fé, e o estabelecimento da crítica de racionalidade que permite à fé melhor se compreender e, portanto, melhor compreender o humano em sua relação com Deus. Em cristianismo, a fé baseia-se na revelação do Deus que vem ao encontro da humanidade, movimento ao qual corresponde a atitude humana de abertura e de resposta livre, na aceitação de tal visitação. Sua recusa impede, evidentemente, a afirmação da fé. O trabalho da teologia corresponderá ao procedimento da racionalidade que buscará compreender o ser de Deus que vem ao encontro do humano, o ser do humano que é visitado por tal alteridade, e o tipo de relação que se estabelece entre eles. Sendo assim, a teologia tendo seus procedimentos já estabelecidos, porque deverá aproximar-se da literatura? A questão pode ser colocada, igualmente, em sentido oposto. A literatura se realiza a partir de realidades humanas e, em seus procedimentos específicos, retrata e afirma o humano a partir do imaginário do autor e da relação estabelecida com o leitor através, exatamente, do texto construído de forma artística. Embora falem do humano, e isto já é importantíssima constatação que permite o relacionamento entre elas, teologia e literatura o fazem de maneira diversa, com objetivos diferentes, e talvez até com distintas visões do que significa ser humano. De certa forma, este também é o campo de trabalho de todas as ciências que, no limite, procuram entender o ser humano em sua realidade, e também é o procedimento de todas as artes, que também expressam uma visão de ser humano. O que é que haveria de especial na relação entre teologia e literatura que exigiria uma atenção e um procedimento especial, diferente dos processos estabelecidos entre, por exemplo, literatura e psicologia, ou entre teologia e filosofia? Haverá diferenças de procedimentos? Talvez haja, pela especificidade da teologia mais que pela forma de se estabelecer da literatura, e talvez daí derivem, também, as dificuldades encontradas para que elas se relacionem.

Há quem diga que a teologia se interessa pela literatura porque esta seria uma maneira mais atraente e, por isso, eventualmente, mais eficiente de comunicar as verdades da fé. Aqui teríamos a literatura reduzida à condição de "serva da teologia", vista apenas como "meio de comunicação". Outros, por se oporem a isto que é visto como arrogância da teologia ou por não quererem adentrar o universo da confissão de fé, preferem estabelecer o diálogo da literatura com o religioso ou, então, utilizá-lo como instrumento para argumentar contra a doutrina ou a prática eclesial. Parece que tais posições têm em comum o fato de tomarem a relação entre teologia e literatura como impossível ou, 
no mínimo, dispensável. A literatura segue seu caminho e se estabelece independente das correntes teológicas ou as atitudes eclesiais; no sentido inverso, a teologia se estabelece sem tomar em consideração a forma de realização da crítica literária ou as escolas hegemônicas em literatura. Assim, impermeáveis uma à outra, a aproximação entre elas seria, talvez, exótica, folclórica, e seu interesse se reduziria a isso. Claro que sempre poderá ser interessante para o autor literário conhecer algo do que se diz em teologia para complexificar seu enredo; assim como os personagens podem discutir questões cósmicas ou químicas, podem também discutir questões teológicas, pois religião se encontra em toda parte, e a teologia tem algo a ver com isso. A teologia terá a oportunidade de "fazer algo diferente" ao se aproximar da literatura, não apenas "servindo-se" de sua forma de comunicação, mas criando uma espécie de "apêndice de curiosidade", algo como organizar um passeio ao redor da estética, que não traz consequências mais profundas. Seria, no máximo, outra forma de afirmar o que ela já afirma ou já conhece por outros caminhos. Em tais procedimentos, não haveria realmente relação ou diálogo entre teologia e literatura, e talvez não haja nem respeito de uma à outra.

Gosto de pensar que teologia e literatura são diferentes, mas se respeitam, se encontram, dialogam e estabelecem relação. E gosto de pensar também que tal relação, de alguma forma, as modifica, como acontece com qualquer relação das coisas humanas. Não posso me pronunciar sobre as transformações eventuais que a literatura possa sofrer com o fato de aproximar-se da teologia, mas posso tentar refletir, a partir da teologia onde me situo, como esta é afetada por sua aproximação do universo literário. Já foi afirmado antes que não é qualquer tipo de teologia que aceita aproximar-se e dialogar com a literatura. Vinda de qualquer horizonte confessional, a teologia terá de não apenas respeitar a literatura em sua alteridade, mas terá de ser capaz de afirmar a dignidade e o valor da humanidade, a importância da cultura e da sociedade, e deixar-se influenciar por estas realidades. Ela terá de ser capaz de diálogo com o humano e com o mundo, sem se situar como o único caminho de acesso à verdade ou no monólogo de ser sua possuidora; deverá reconhecer e valorizar a alteridade, sem querer reduzir tudo ao mesmo, de si ou do outro, exatamente para poder estabelecer relação; terá de ser uma teologia capaz de transformar-se, de inserir-se no processo histórico da existência humana, e talvez assim ela possa ser mais significativa.

Mas há um outro ponto a considerar, que eu gostaria de abordar aqui. $\mathrm{O}$ encontro da teologia com a literatura não é simplesmente acidental ou dispensável; talvez seja mesmo necessário para que a teologia seja ela mesma. Seria 
mais do que afirmar que no encontro com a literatura a teologia se transforma, mas seria, talvez, afirmar que ela se realiza como teologia exatamente no encontro com a literatura. $\mathrm{O}$ que está em jogo aqui é a própria epistemologia teológica, sua maneira de proceder, de compreender-se e de aceder ao conhecimento que lhe é próprio e específico. Claro que para isso não bastará dizer que os textos bíblicos ou magisteriais sobre os quais a teologia reflete são, exatamente, textos e, por isso, já haveria uma proximidade com a literatura. Aqui estaríamos ainda no "acidental" de tal relação. Também não será o caso de relativizar a revelação, tal como reconhecida pela fé, para afirmar sua presença em qualquer texto de qualquer autor literário. Há um primado do texto bíblico que não pode ser esquecido, e a importância dos textos magisteriais também não pode ser relativizada. Aqui estaríamos na simples negação da teologia ou, ao menos, em uma não compreensão do que ela seja ou significa. Podemos, então, vislumbrar a pergunta sobre a presença de questões literárias na realização mesmo da reflexão teológica; dito de outra maneira, a literatura tem algo a ver com a "fides quaerens intellectum", tradicional compreensão do que seja a teologia?

\section{Exegese literária}

Se a resposta a esta questão não pode ser excessivamente rápida, será importante perceber o que já se realiza no ambiente teológico em relação aos procedimentos literários. Podemos citar como exemplo a exegese literária, método de leitura dos textos bíblicos em perspectiva de literatura, que leva a sério a narratividade presente nos textos da Escritura. Trata-se do método de ler os textos bíblicos como construídos por seu autor buscando efeitos que decorrem de procedimentos e códigos especificamente literários. Não busca compreender a história que precede o texto ou a história de sua transmissão, mas busca tomá-lo em sua "imanência de texto literário", na objetividade do "mundo do texto", buscando compreender os procedimentos pelos quais o autor definiu sua estratégia para suscitar os efeitos desejados no leitor. Tal método exegético estuda o texto em sua sincronia e em suas funções, possibilitando a compreensão de sentido que lhe dá aquele que lê o texto enquanto segue as indicações ou sinais com os quais o autor marcou seu texto. Lê-se, então, o texto bíblico como texto narrativo, onde o que é destacado não é a eventual referência a fatos históricos, mas os aspectos que relevam da poética ou retórica da narratividade, da análise das estruturas textuais, da hermenêutica, etc. Não retira, com isto, o "caráter sagrado" do texto bíblico, pois continua tomando em consideração sua relação 
com a fé, mas busca compreender melhor o texto para melhor compreender a revelação de Deus que ele apresenta, sem se prender a um sentido já definido ou à veracidade do fato narrado. Para além do fato histórico e da história do texto, o que temos diante dos olhos é um "texto literário", a ser lido por procedimentos e técnicas que relevam da análise literária. Desta maneira, a leitura da Escritura se faz diferentemente a partir da relação da teologia com a literatura. Não estamos mais no terreno de um relacionamento acidental, mas necessário até, pois releva da compreensão dos princípios sobre os quais se constrói a afirmação de fé.

Uma das características principais do cristianismo, senão aquela que the é fundamental, é a percepção da presença e da ação de Deus que se revela na história da humanidade. O cristianismo, seguindo a maneira de ser do judaísmo, afirma a presença de Deus na história humana, e nisto ele se diferencia das mitologias antigas e tradicionais. Ele não conhece uma cosmogonia nem uma luta dos deuses, mas confessa sua presença no meio da humanidade. Trata-se de um Deus conosco presente na história humana e que pode ser percebido nesta mesma história. É precisamente a fé que se abre à presença de Deus que poderá reconhecer sua presença nos acontecimentos da história, fé que será suscitada por aquele acontecimento histórico no qual Deus se faz presente. Assim, temos uma primeira constatação, fundamental em cristianismo, que é aquela de dizer que há uma presença de Deus na história ou, dito de outra maneira, que há um fato histórico de revelação de Deus. A fé cristã não se constrói sem referência à história, pois senão se tornaria mitologia ou ilusão. Por isso, suas afirmações centrais repousam sobre eventos históricos: a criação, a encarnação, a redenção, a escatologia, enfim, os pontos fundamentais do cristianismo, são vistos e afirmados como eventos históricos. A afirmação da fé constrói-se sobre a historicidade do fato, como sua interpretação e compreensão de significado.

É igualmente importante perceber que a fé se relaciona com a história e nela se baseia, mas não dispensa a afirmação de sentido. Há um fato histórico, a crucificação de Jesus por exemplo, mas não se dispensa a interpretação que diz do significado de tal acontecimento, e este significado, finalmente, é que constituirá a afirmação da fé e a posterior elaboração do que se conhece como doutrina. Nenhum fato histórico tem significação evidente, será sempre relido e interpretado. Assim acontece com a fé, que afirma não só a historicidade de um galileu crucificado, mas afirma que neste acontecimento Deus se revela como salvador. Temos aqui, assim, o conhecido binômio fé e história: a fé se afirma sobre e a partir do acontecimento histórico, sem o qual estaríamos em 
mitologia, mas não basta à fé afirmar o acontecimento, mas sim estabelecer seu significado, exatamente onde ela pode reconhecer e apontar a presença de Deus. Aquilo que será preciso perceber é que entre o fato histórico e a afirmação da fé e consequente estabelecimento da doutrina, temos um texto literário. É o texto que faz a mediação entre a história e a fé. E um texto que, no caso dos evangelhos e de outros tantos textos bíblicos que se referem à história, é narrativo, é literário.

Durante muito tempo se pensou que a bíblia era um livro de história, narrando fielmente os acontecimentos a que ela se refere. Assim, se ela diz que pereceram 400 profetas de Baal, é porque pereceram 400 profetas de Baal; se ela diz que Jacó lutou com um anjo, é porque ele lutou com um anjo; se ela diz que, no episódio conhecido como "multiplicação dos pães", comeram 5 mil homens sem contar mulheres e crianças, é porque assim foi e este número é exato; se ela afirma que Lázaro saiu para fora do túmulo ainda com as faixas mortuárias, é porque isso aconteceu realmente desta maneira. Sabemos a que conduz, nos tempos atuais, este tipo de leitura fundamentalista da Escritura. Os recentes documentos da Igreja condenam tal forma de leitura da bíblia. Por outro lado, sobretudo depois do método exegético histórico-crítico que se baseia na crítica histórica e busca compreender e reconstruir os eventos históricos aos quais a bíblia se refere levando em consideração sobretudo a época da redação dos textos bíblicos e a história de sua transmissão, passou-se a ver que a bíblia é um livro teológico e não de registros históricos. Assim, para além da verificação da historicidade do fato, o que foi colocado em destaque era o sentido teológico que o texto atribuía àquele evento. Buscou-se de tal forma enxergar como foi realizada a construção teológica dos textos bíblicos que até mesmo se poderia considerar como menos importante a realidade dos fatos históricos.

Não se trata de fazer uma opção entre um e outro nem de buscar um meio termo entre eles. Trata-se de simplesmente perceber que, entre o fato histórico como tal e a compreensão de fé da igreja, temos um texto literário, um texto composto em forma de narração e não em forma de apresentação de conceitos científicos. Se Deus não pode ser dito, pode ser narrado. A narração é a maneira de nos referirmos à revelação de Deus na história da humanidade; ela sucede o fato histórico e antecede a confissão de fé. O texto narrativo não descreve simplesmente o que aconteceu, mas o reelabora, o ressignifica, colocando em destaque aspectos que querem favorecer certa compreensão e reação daquele que lê; por outro lado, ele não é compilação dogmática das afirmações da fé, ele narra histórias e acontecimentos, não faz resumo do que 
se crê, mas a reelaboração do fato aponta para o sentido que se quer afirmar, e com isso ele indica uma "confissão de fé" que, por procedimentos literários, é ao que se quer conduzir o leitor. Estes procedimentos literários relevam da arte de compor, do referencial estético, da arte de narrar prendendo a atenção e fazendo recurso, não raro, ao imaginário e à ficção. O surgimento da palavra "ficção" pode causar estranheza e mal-estar, sobretudo diante da compreensão de que a fé deve ser verdadeira e a teologia, expressão desta verdade. Mas não é preciso temer a ficção, que pode ser falsa quando refere a fatos históricos, mas pode não sê-lo quando se refere ao sentido e ao significado. Paul Ricoeur já havia afirmado, há muito tempo, que a ficção é também forma de se aproximar do real, e que história e ficção podem completar-se no que se refere à compreensão de sentido do mesmo real. Afinal, mais do que se referir a fatos, nos referimos a vidas.

O texto não é a história, e não é a afirmação de fé. Ele se coloca entre ambas, ligando-as ou possibilitando sua ligação. A teologia, que não é estudo da história mas nela se baseia, e que não é afirmação da fé mas busca de sua compreensão, só cumpre sua função se levar em consideração a densidade, a imanência e a realidade do texto literário que é sua referência fundamental. Com isso creio dar por demonstrado a importância para a teologia, ao menos em exegese, de se levar em conta procedimentos literários, de se tomar a sério a literatura e de perceber como ela pode ajudar a melhor compreender a confissão de fé.

\section{A questão epistemológica}

Por outro lado, e aqui apenas aceno à questão e remeto para outros estudos, a elaboração teológica enquanto tal, naquilo que tem de específico, não se fará sem certa dose de imaginação. E isto não será depor contra sua razoabilidade ou credibilidade, pois não é preciso tomar em sentido negativo palavras como ficção, poesia ou imaginação. Se pudemos confirmar a importância da literatura para a exegese bíblica, nem por isso se disse de sua pertinência à elaboração sistemática da teologia. Creio que aqui também, e esta é a hipótese que defendo, a literatura será importante para a compreensão da afirmação de fé. A apresentação de Deus de maneira narrativa diz de sua identidade. Um Deus que não é dito, mas é narrado, tem apresentado seu comportamento e é isso que o identifica mais do que teorias ou conceitos vindos de outros horizontes. À pergunta “quem é Deus?" não se responde de maneira conceitual, mas narrativa, como o fazem, aliás, os símbolos de fé do cristia- 
nismo. $\mathrm{O}$ fato de ser apresentando, ou se apresentar, de maneira narrativa não é só limitação da linguagem humana, mas opção, escolha de Deus, que assim revela sua identidade e que podemos conhecer como, segundo as palavras de Gesché, "identidade narrativa". A isso se referem todos os conteúdos da fé cristã, aos quais acedemos por via de narração. Aqui a literatura não informa a teologia apenas em suas conclusões finais, mas em seu modo de proceder. A teologia que se aproxima da literatura não tem apenas algumas conclusões diferentes, mais bonitas ou poéticas, mas tem sua epistemologia de alguma forma informada por ela, de maneira que sua poesia não se verá constituída no final, mas ela toda se fará de forma poética. Não seria uma forma melhor de corresponder àquele que é o poeta criador de toda a poesia?

\section{Referências Bibliográficas}

GESCHÉ, Adolphe, O Cristo, col. Deus para pensar, vol. 6, São Paulo: Paulinas, 2004.

MANZATTO, Antonio, Teologia e literatura, São Paulo: Loyola, 1994. RICOEUR, Paul, Tempo e narrativa, São Paulo: Papirus, 1994.

Antonio Manzatto

Professor da PUC-SP

Doutor em Teologia pela Universidade Católica de Lovaina, Bélgica

Artigo Recebido em 07/09/2011

Artigo Aprovado em 04/11/2011 